\title{
ON THE CLINICAL VALUE OF BLOOD ANALYSES IN NEPHRITIS IN CHILDHOOD.
}

BY

\author{
G. A. HARRISON, B.A., M.D.,
}

Chemical Pathologist, St. Bartholomew's Hospital, and

W. G. WYLLIE, M.D., M.R.C.P.,

Assistant Physician, Hospital for Sick Children, Great Ormond Street.

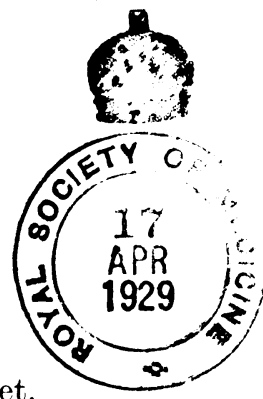

(From the Hospital for Sick Children, Great Ormond Street, London).

The following analyses (Tables I and II) confirm the work of previous investigators. The series is, however, fairly extensive, and serves as the basis of a short discussion on the value of such estimations in clinical medicine.

Urea was estimated by the urease method, using $3 \mathrm{c.cm}$. of blood. Cholesterol and plasma proteins were determined colorimetrically, according to the techniques of Myers and Wardell $\left({ }^{2}\right)$, and of $\mathrm{Wu}^{(3)}$ respectively. The tables are self-explanatory.

TABLE I.

Blood Cholesterol and Urea in Nephritis.

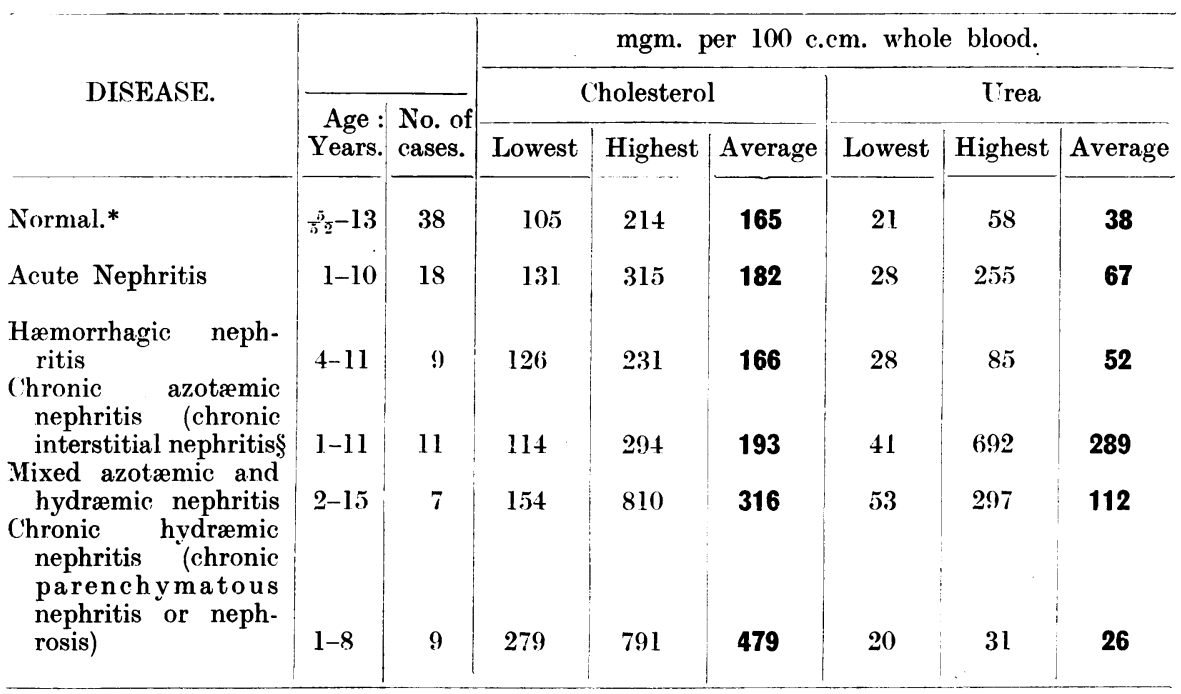

* Many of these were convalescent surgical cases. The rest were medical cases, excluding renal diseases and all conditions in which hypercholesterolæmia might be expected (e.g. diabetes mellitus, hepatic lesions, xanthomatosis, etc)..

Most of these cases were renal dwarfs. 
TABLE II.

Plasma Proteins in Nephritis.

\begin{tabular}{|c|c|c|c|c|c|c|c|c|c|c|c|}
\hline \multirow{2}{*}{ 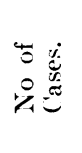 } & \multirow{2}{*}{ 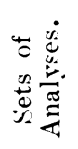 } & \multirow{2}{*}{\multicolumn{2}{|c|}{ Types of Nephritis. }} & \multicolumn{3}{|c|}{$\begin{array}{l}\operatorname{mgm} \text {. per } 100 \mathrm{c.cm} . \\
\text { whole blood. }\end{array}$} & & $\begin{array}{l}\text { lasma } \\
\text { per } 11\end{array}$ & $\begin{array}{l}\text { oteins } \\
\text { c.cm. I }\end{array}$ & ima & \multirow{2}{*}{$\begin{array}{l}\text { (ilobulin } \\
\text { \% of } \\
\text { protein. }\end{array}$} \\
\hline & & & & Age & Lrea. & r'holest. & Fibrin. & Alb. & Gilob. & Total & \\
\hline$s$ & 10 & Acute & $\begin{array}{l}\text { Min } \\
\text { Max } \\
\text { Av }\end{array}$ & $\begin{array}{r}1 \\
10 \\
-\end{array}$ & $\begin{array}{r}25 \\
105 \\
57\end{array}$ & $\begin{array}{l}145 \\
315 \\
182\end{array}$ & $\begin{array}{l}0 \cdot 247 \\
0 \cdot 745 \\
0 \cdot 460\end{array}$ & $\begin{array}{l}2 \cdot 8+1 \\
5 \cdot 04 \\
4 \cdot 16\end{array}$ & $\begin{array}{l}1 \cdot 76 \\
3 \cdot 15 \\
2 \cdot 41\end{array}$ & $\begin{array}{l}5 \cdot 02 \\
8 \cdot 27 \\
6 \cdot 93\end{array}$ & $\begin{array}{l}25 \\
4 !) \\
35\end{array}$ \\
\hline 7 & 8 & Acute Hiemorrhagic & $\begin{array}{l}\text { Min } \\
\text { Max } \\
\text { Av }\end{array}$ & $\begin{array}{r}4 \\
10 \\
-\end{array}$ & $\begin{array}{l}23 \\
73 \\
44\end{array}$ & $\begin{array}{l}129 \\
231 \\
171\end{array}$ & $\begin{array}{l}(0 \cdot 282 \\
0 \cdot 575 \\
0 \cdot 446\end{array}$ & $\begin{array}{l}3 \cdot 91 \\
5 \cdot 47 \\
4 \cdot 80\end{array}$ & $\begin{array}{l}2 \cdot 02 \\
2 \cdot 97 \\
2 \cdot 47\end{array}$ & $\begin{array}{l}(i \cdot 99) \\
8 \cdot(i 6 \\
7 \cdot 72\end{array}$ & $\begin{array}{l}26 \\
39 \\
32\end{array}$ \\
\hline 4 & 4 & $\begin{array}{l}\text { Chronic Azotiemic } \\
\text { (chronic interstitial) }\end{array}$ & $\begin{array}{l}\text { Min } \\
\text { Max } \\
\text { Av }\end{array}$ & $\begin{array}{r}1 \\
12 \\
-\end{array}$ & $\begin{array}{r}41 \\
592 \\
297\end{array}$ & $\begin{array}{l}119 \\
201 \\
165\end{array}$ & $\begin{array}{l}0 \cdot 380 \\
0 \cdot(i 1: 3 \\
0 \cdot 524\end{array}$ & $\begin{array}{l}3 \cdot 19 \\
(i \cdot()() \\
4 \cdot 40\end{array}$ & $\begin{array}{l}1 \cdot 28 \\
: 3 \cdot 5 i \\
2 \cdot 29\end{array}$ & $\begin{array}{l}5 \cdot s 2 \\
s \cdot 40 \\
7 \cdot 21\end{array}$ & $\begin{array}{l}16 \\
4+ \\
31\end{array}$ \\
\hline 3 & 4 & $\begin{array}{l}\text { Mixed Azotionicand } \\
\text { Hydramic: }\end{array}$ & $\begin{array}{l}\text { Min } \\
\text { Max } \\
\text { Av }\end{array}$ & $\begin{array}{r}\bar{b} \\
10 \\
-\end{array}$ & $\begin{array}{r}40 \\
297 \\
140\end{array}$ & $\begin{array}{l}190 \\
2(i 1 \\
231\end{array}$ & $\begin{array}{l}0 \cdot+(1)() \\
0 \cdot 772 \\
0 \cdot 555\end{array}$ & $\begin{array}{l}2 \cdot 14 \\
4 \cdot 4: 3 \\
3 \cdot 43\end{array}$ & $\begin{array}{l}1 \cdot 87 \\
3 \cdot 50 \\
2 \cdot 51\end{array}$ & $\begin{array}{l}4 \cdot 54 \\
8 \cdot 33 \\
6 \cdot 50\end{array}$ & $\begin{array}{l}31 \\
42 \\
38 \cdot 5\end{array}$ \\
\hline 5 & (i & $\begin{array}{l}\text { Chronic Hydramic } \\
\text { (chronic parenchy- } \\
\text { matous or nephrosis) }\end{array}$ & $\begin{array}{l}\text { Mini } \\
\text { Max } \\
\text { Av }\end{array}$ & $\begin{array}{r}2 \\
8 \\
-\end{array}$ & $\begin{array}{l}20 \\
39 \\
29\end{array}$ & $\begin{array}{l}279 \\
66(j \\
436\end{array}$ & $\begin{array}{l}0 \cdot 370 \\
0 \cdot 656 \\
0 \cdot 519\end{array}$ & $\begin{array}{l}1 \cdot 51 \\
2 \cdot 58 \\
\mathbf{2} \cdot 01\end{array}$ & $\begin{array}{l}1 \cdot 10 \\
2 \cdot 59 \\
1 \cdot 96\end{array}$ & $\begin{array}{l}2 \cdot 61 \\
5 \cdot 55 \\
4 \cdot 18\end{array}$ & $\begin{array}{l}42 \\
51 \\
46 \cdot 5\end{array}$ \\
\hline
\end{tabular}

The results have been collected from the records of the Hospital for Sick Children, Great Ormond Street, over a period of two years (1925 and 1926). One of us (G.A.H.) collected the laboratory data, and sent the names of the patients to the other (W.G.W.), who tabulated the cases, according to the types of nephritis they presented on clinical examination. The great majority of the patients had been under observation during the time when one of us (W.G.W.) was Medical Registrar to the Hospital. The classification of the different types of nephritis is therefore according to a uniform plan (see $\left.{ }^{(4)}\right)$. No doubt in certain instances the laboratory data influenced the actual labelling of the case when in hospital, but by reviewing our results after an interval in the way described, we think the risk of making the diagnoses fit the figures has been reduced to a minimum.

\section{Blood Cholesterol Estimations.}

It will be seen from Table I, that the average blood cholesterol for the different groups agrees with accepted teaching. If, however, the ranges for the several groups are compared, it will be seen that the cholesterol content of the blood may be of very little diagnostic value in an individual case. It may be concluded that figures over $300 \mathrm{mgm}$. per $100 \mathrm{c.cm}$. are practically confined to the hydræmic types of nephritis. In all these cases the œdema was of a gross character, and the cholesterol estimation was really superfluous from the point of view of classifying the type of nephritis. Cholesterol estimations afford no means of distinguishing between those cases which have 
commenced as nephrosis, and those which may be called chronic parenchymatous nephritis or nephrosis, but which have developed subsequent to an attack of acute nephritis. The initial inflammation of the kidney in the latter type having passed off, it is probable that the later state of the kidney is the same in both classes. It is interesting to note that marked hypercholesterolæmia may be associated with nitrogenous retention, and is not confined to cases of nephrosis. Figures under $300 \mathrm{mgm}$. per $100 \mathrm{c.cm}$. may be found in any of the different groups, and are then of no value in assessing the type of nephritis.

On the whole we have found that the cholesterol estimations are of little or no practical value in the diagnosis, prognosis or treatment of nephritis in children.

\section{Blood Urea Estimations.}

The importance of estimations of the urea content of the blood is of course well established, and needs no further elaboration. One point, to which we wish to draw attention, is that the normal range for children under twelve is apparently higher than that for adults by some $10 \mathrm{mgm}$. per $100 \mathrm{c.cm}$. In this respect the young are like the old, though the cause of the higher figures at the extremes of life is presumably different. The metabolism of children is more vigorous than that of adults, and this may be the cause of the higher figures in the former group. In old age the higher blood urea is probably due to the kidneys being less efficient than in young and adult life.

Determination of the blood urea-content is the only sure method of discriminating between mixed azotomic plus hydromic and chronic hydromic nephritis. Oedema may be almost as gross in the first as in the second. The mixed form, in fact, in the absence of red blood corpuscles in the urinary deposit, or possibly cardio-vascular changes, is often clinically indistinguishable from chronic hydræmic nephritis. A high figure, therefore, for the blood urea in a chronic œdematous case is certain evidence of interstitial plus parenchymatous change in the kidneys. The point is of prognostic importance, the outlook being decidedly less favourable in the mixed form of nephritis.

As regards the general utility of blood urea estimations, our experience agrees with the general consensus of opinion, that they are often invaluable in the diagnosis, prognosis and treatment of nephritis.

\section{Differential Estimations of Plasma Proteins.}

Table II shows the findings for the differential estimation of the plasma proteins in the nephritides of children. It will be seen that the percentage of fibrin is almost invariably raised in all types. There would appear to be no special value in this particular analysis. The usual value for this constituent normally lies between 0.20 and 0.38 per cent.

The values for albumin, globulin, total protein, and globulin percentage of the total protein, for the three groups, " acute," "acute hæmorrhagic," and "chronic interstitial," generally fall within the normal limits, as given by previous workers. The normal limits are: albumin 4.5 to $6 \cdot 7$, globulin $1 \cdot 2$ 
to $2 \cdot 7$, total protein $6 \cdot 7$ to $8 \cdot 6$ per cent., and globulin, as percentage of total protein, 16 to 40 per cent. The two groups of hydræmic nephritis alone remain for consideration. It will be seen that our results simply confirm previous work in that the total protein is decreased, and that this decrease is more at the expense of the albumin than of the globulin fraction. We have not, however, observed such extreme losses of albumin as those recorded by Epstein( $\left.{ }^{(}\right)$.

The average composition of the sera in Epstein's cases is given in Table III for comparison.

\section{TABLE III.}

Epstein's Analyses for Comparison with Table II.

\begin{tabular}{l|c|c|c|c}
\hline \multicolumn{1}{c}{ Sera. } & \multicolumn{3}{c}{ Gm. per 100 c.cm. } & Globulin \\
& Total & Albumin & Globulin & per cent. \\
\hline Normal & $7 \cdot 400$ & $4 \cdot 662$ & $2 \cdot 738$ & $37 \cdot 0$ \\
$\begin{array}{l}\text { Cardiac conditions } \\
\text { Chronic interstitial nephritis }\end{array}$ & $6 \cdot 408$ & $+6 \cdot 717$ & $2 \cdot 240$ & $33 \cdot 9$ \\
$\begin{array}{l}\text { Chronic parenchymatous } \\
\text { nephritis }\end{array}$ & $3 \cdot 928$ & $0 \cdot 466$ & $3 \cdot 462$ & $35 \cdot 7$ \\
\hline
\end{tabular}

Our results apply to the plasma, and therefore include $\mathrm{t}_{\mathrm{b}} \mathrm{brin}$, whereas his figures are for sera. The fibrin, however, is but a small percentage of the total protein, and so we have not recalculated our globulin percentag 3 in terms of the serum total protein as opposed to the plasma total protein. It $\mathrm{w}$ ll be seen that in Epstein's cases of chronic parenchymatous nephritis the average globulin content is actually higher than in the normal group, whereas in ours it is a little below the normal. This fact, coupled with the lesser loss of albumin in our cases, accounts for the marked difference between the globulin per cent. of total protein in the two series : $89 \cdot 2$ in Epstein's series as against 46.5 (or 46.9 if expressed as percentage of the serum total protein) in our series.

The changes in the plasma proteins in the group of mixed azotæmic and hydræmic nephritis are similar to those in the group of chronic hydræmic nephritis, though less marked in degree.

Our opinion as to the clinical value of estimations of the plasma proteins is the same as that expressed for cholesterol determinations. The analyses are really superfluous. Grossly abnormal figures only occur in nephritis with marked œdema. That does not imply, of course, that all cases of severe odema of whatever origin will invariably show these changes. Patients, for instance, with purely cardiac odema may not, but there is no need to make a differential estimation of the plasma proteins in order to distinguish cardiac from renal œdema. In our experience, these protein analyses are of little or no help clinically in the diagnosis, prognosis or treatment of nephritis.

We do not wish to give the impression that we regard much of the biochemical work of the above nature as altogether useless. It has undoubtedly played an important part in studying the pathology of œdema, etc., 
etc., and such analyses will continue to be of value in research work. It is, however, of advantage to the clinician to realise what chemical tests are of value to him in the care of his patients, and it is also desirable that the laboratory worker should not be overburdened with lengthy analyses, which will be of no practical use to his clinical colleague. Co-operation between clinician and laboratory worker is essential, both in planning work which will assist in the improvement of a patient's condition, and in undertaking investigations which may lead to new knowledge of disease and its pathology.

We wish to thank those members of the Staff of the Hospital, to whom we are indebted for the use of cases, and Mr. R. J. Bromfield and Miss E. M. Taylor for their technical assistance.

\section{SUMMARY.}

1. The cholesterol and urea content of whole blood has been determined, and a differential estimation of the plasma proteins has been made in a series of cases of nephritis. The results confirm the work of previous investigators.

2. As a guide to the clinical control of a case the urea estimations are often of great value; the cholesterol and plasma determinations are generally superfluous.

3. As an aid to the classification of the type of nephritis, the same conclusion applies.

\section{REFERENCES.}

1. Epstein, A. E., Am. J. Med. Sci., Philad., 1917, CLIV, 638.

2. Myers, V. C., and Wardell, E. L., J. Biol. Chem., N.Y., 1918, XXX̣VI, 147.

3. Wu, H., Ibid., 1922, LI, 33.

4. Wyllie, W. G., and Moncrieff, A., Lancet, Lond., 1926, i, 128. 